navigation and surveying; or except for the part of solar physics which has an immediate bearing on terrestrial affairs. It is admitted that a very strong utilitarian case cannot be made out for modern astronomy and, in spite of apparent exceptions, much stronger arguments for astronomy can be made on æesthetic grounds. Civilized man should have as much appreciation of astronomical discovery as he has of architecture, music, the drama, or even of pure mathematics or philosophy. Good popularization of astronomy, as indeod of any science, is a difficult task, and it is suggested that professional astronomers should consider it their duty to devote a certain amount of time to explaining the aims and achievements of astronomy to the general public, or even to fellow men of science, who are sometimes very ignorant of the subject.

Financial problems may be acute in the future needs of astronomy, and a great weakness in the organisation of astronomy hitherto has been the existence of so many small units. Fusion into a few large units should be economical and would lead to greater efficiency, but it is admitted that the difficulties of fusion are almost unsurmountable. Another unfortunate matter is the erection of telescopes in places where comparatively little use can be made of them, and it does not seem that any great improvement here can be expected in the near future. A much more serious problem is the question of the supply of trained personnel. The absence of new recruits during the War, and the fact that higher salaries have induced some astronomers to turn their attention to other branches of science, are serious factors and will have a profound effect on astronomy for some time. On the other hand, post-war technical developments may push observational astronomy into new channels-perhaps a V2 rocket will be able to take an ultra-violet spectrograph above the ozone layer of the earth's atmosphere. Finally, although astronomers in different countries may resume friendly co-operation, nevertheless travelling may be expensive and hedged about with restrictions, so that international co-operation may not materialize on the scale that we desire. At the end. of the article it is suggested that, "The enthusiasm and ability of amateurs, to which we have owed so much in the past, may yet prove the principal means of salvation for astronomy in a difficult future '.

Bats and their Ways

ON p. 46 of fers issue, Dr. Donald R. Griffin deals with the hsion of the work he did, in association. with Dr Ropprt Galambos, on the supersonic cries of bats. for July issue of the National Geographic Magatine, Dr. Griffin gives a descriptive account of his work on bats, with several excellent photographs showing the winter haunts of bats, their movements in flight and the laboratory equipment devised to test their power of avoiding obstacles. During his investigations, which have extended over the past fourteen years, Dr. Griffin has given particular attention to bats of New England, including many species of the little brown bats (Myotis), pipistrelles (Pipistrellus subflavus and related species) and the big brown bat (Eptesicus f. fuscus). Some 13,000 bats have been marked with aluminium bird bands, from the recovery of which it has been ascertained that they have good powers of homing; and although the 'cave bats', as they are termed, hibernate, they also are known to migrate distances up to 150-170 miles to find, or return to, suitable winter quartersoften disused mine-workings and liméstone caves. The use of the high-speed camera with simultaneous cinematograph pictures shows that, when flying, bats make about fifteen strokes of the wing each second and that their flying speed is appreximately 10 miles an hour.

\section{Universities Federation for Animal Welfare}

"A Trme of gtot activity lies before us," says the annual repopor for 1945 of the Universities Federation for Whimal Welfare, and all who have at heart the interests of animals and the attitudes of man twiards them will wish that activity great suogosis under the new president, Dr. E. Hindle. The Federation's contacts with the Parliamentary and Scientific Committee have widened its influence. An alteration in the regulation regarding the preparation of vaccine lymph has been amended in response to the Federation's representations to enforce the killing of the calf before the lymph is collected. Regulations concerning the open trapping of animals and the control of rabbits are being discussed with the Ministry of Agriculture. Among the Federation's principal aims are the introduction of humane methods of pest control, and much thought and consultation with other organisations have been given to methods of destroying rats. The Federation hopes to issue shortly its "Handbook on the Care of Laboratory Animals", which Messrs. Baillière, Tyn. dall and Cox are to publish. The expert information in this book should make it valuable, not only to laboratory workers, but also to many others. Nine lecturettes for children have been added to the Federation's publications, and the film library has been greatly appreciated by schools. A feature of the Federation's publications are the drawings by its honorary artist, Fougasse.

\section{Dry Rot in Wogd}

A FOUR'H gdition of the brochure on "Dry Rot in Wood" has ${ }^{*}$ een issued from the Forest Products Research, Iaboratories, under the auspices of the Department of Scientific and Industrial Research (Bull. (F̌o. 1. H.M. Stationery Office, London, 1945). A d dieason for the re-issue, it is said that, since the outbreak of war, dry rot has become much more prevalent, owing to the general neglect of the upkeep of buildings, and damage caused by bombing, to which may be added fire damage. Serious and extensive outbreaks of dry rot developed in a number of buildings after fires caused by incendiary bombs. Much of this rot might have been avoided had certain precautions been taken. In the re-issue of the Bulletin, new material has been incorporated, and the section dealing with new buildings has been revised; certain precautions being necessary to prevent decay in timber in some of the newer types of construction now coming in use. Dry rot has always been one of the more or less concealed dangers in a house-especially in old houses in the ground floors or beneath them, or in old staircases and rooms in the upper portions of old buildings. It is the result of the operations of fungi, and not of insects-the attacks of the latter being usually discernible by the presence of small pin or 'shot' holes in the wood. The attacks are held to be due to faulty building. Doubtless this contention is strictly true; but there are many delightful old buildings in which any alterations would detract from their beauty, faulty 
as this construction may be from the point of view of dry rot. The new edition of this Bulletin may be strongly recommended to those responsible for present building programmes, so that features likely to encofyage dry rot may be avoided.

\section{6 \\ South Australian Musgywn}

Among the scielftifle papers mentioned in the report of the Sopth Australian Museum for the period Julf 1944, to June 30, 1945 (Adelaide, 1945) is onepy $\mathrm{H}$. 'Womersley, "Acarina of Australia and Thew Guinea. Family Leeuwenhoekiidæ" (Tralns. Roy. Soc. S. Australia, 69, (1), 96). Mr. Womersley has published several other papers on the Acarina in the Records of the South Australian Museum, notably, in collaboration with Dr. W. G. Heaslip, on the Trombiculinæ or itch mites, certain species of which have been responsible for scrubtyphus and scrub-itch among troops operating in New Guinea and the Pacific Islands. The taxonomic research on these has been centred in the South Australian Museum. Numerous specimens of Trombiculinæ were collected by Dr. Heaslip in North Queensland, and by Dr. C. M. Gunther in New Guinea during their researches upon typhus fevers during the war period. It is reported that the Board has had under consideration the possibility of post-war extension of the Museum. The present congestion of both exhibition and storage space is acute, and it is now felt that the condition endangers the proper conservation of the collections, many of which are of a unique character and of inestimable value. The report also refers to needs in respect of the Museum's educational work, especially that connected with visiting school-classes. Hitherto the greater part of this service has fallen upon members of the scientific and technical staffs; but it is now felt that the position results in the inadequate employment of specialized qualifications. The situation could be relieved if the Education Department were to appoint two special teachers to act in co-operation with the Museum staff and to take charge of the school classes. It is pointed out that a similar arrangement is in operation in other Australian museums and that it has ppgred highly successful.

Introduction to Archæological Method

No. 1 of the Hydbook Series produced by the South African Wrrchæological Society is entitled "Method if Prehistory" and is by A. J. H. Goodwin (Cape (Touh. 12s. 6d.); it is an extremely useful litth.book. Prehistoric archæology, whether in Europe or in South Africa, is a fascinating hobby subject, and as such is being increasingly taken up. But there are branches of the subject which are somewhat technical, as, for example, the processes which were used in the manufacture of the tools found, and their classification when collected in the field; also irreparable damage can be done to archæological sites if amateur investigators without knowledge and experience start to excavate unaided. Some kinds of site are so common that little harm is actually done; but there are other rarer types, for example, cave sites or barrows, where the inexperienced amateur may do irreparable damage. Goodwin's book provides just that approach to prehistoric study which many people need. There are chapters on the scope of prehistory, on materials and technology, on field research and excavation, on the preservation and packing of material, on nomenclature, and on the outfit required by an investigator. There is also a useful if short bibliography.

\section{Literature on Soil Insecticides}

THe Imperial Instityte of Entomology has done good service inqisswing "A Review of the Literature on Soil Inssetic.des" (Imperial Institute of Entomology, 41 Qulden's Gate, London, S.W.7. 10s.). Since the subject is one of wide interest and economic imprtance, it is a great advantage to have so much scattered information brought together under one cover. The work took its origin at a Conference on Insecticides and Fungicides of the Agricultural Research Council, which decided to ask Dr. H. C. Gough to prepare the review now before us. The period covered by this work begins in 1914 and ends, except for a few references, in 1940; owing to war conditions, its publication at an earlier date was impracticable. In order to ensure as wide a circulation as possible, the Agricultural Research Council delegated the publication of the review to the Imperial Institute of Entomology. The subject-matter of the review is extremely well arranged under the chemicals employed. The most important of these are grouped together and arranged alphabetically. The remaining substances, also arranged alphabetically, follow ; but they proved difficult to classify owing to their being often referred to by different authors under different names. Many foreign names also proved difficult to translate owing to their often having different significance in different languages. A perusal of the 150 or more pages of this work shows how contradictory so many of the results obtained by different authors have been for almost all the substances tested. It is, therefore, impossible to draw any but very limited conclusions. This in itself is a cogent argument for renewed and carefully controlled experiments. Also the need for a full analysis of the diverse factors likely to influence the results of experiments has to be constantly borne in mind. A very fair indication of the extent of the subject of soil insecticides is given by the bibliography at the end of this review, in which more than 650 works are listed.

\section{Synthetic Philosophy of the Seventeenth Century}

In his Herbert Spencer Lecture for 1945, "Synthetic Philosophy fntere Seventeenth Century : a Study of Early Acian Ce, (Oxford: Basil Blackwell. 2s. net), Canonf C. Raven maintains that popular writers on the history of science are giving us a defective accbunt of the breakdown of the medieval and the development of the modern world, and a caricature of the characters and intentions of the founders of the Royal Society; their metaphysical and religious interests are minimized and the progress which they made towards a synthetic philosophy ignored. Secondly, he points out that almost all the recent histories of science neglect the biological sciences, and especially botany and zoology, treating the subject as if mathematics were the sole primary theme, with astronomy and physies as its derivatives. Canon Raven contends that the remarkable group of men who gathered as the 'Invisible College' meeting at Cambridge, inspired by Robert Boyle and John Wilkins, and expanded in 1662 into the Royal Society, not only brought Britain into the front rank intellectually and almost succeeded in creating an alternative for the medieval synthesis, but were also men of sincere and deep religious conviction, and 